\title{
Editorial
}

Int Neurourol J 2014;18:1-2

http://dx.doi.org/10.5213/inj.2014.18.1.1

pISSN 2093-4777 · eISSN 2093-6931

\section{Let's Pay Attention to the Average}

\author{
Khae Hawn Kim \\ Associate Editor \\ Department of Urology, Gachon University Gil Medical Center, Incheon, Korea \\ E-mail: kimcho99@gilhospital.com
}

Before advancing in every step of development in medicine, researchers may experience a period of agony. However, once that painful step is overcome, progress to the next step is possible. Thanks to such agony, new research products, theories, and technologies are produced, that can be applied in the medical field after undergoing peer-reviews. During these stages of conquest and progress, academic journals play the role of locomotives, carrying new information to intelligent readers. Our journal, the International Neurourology Journal (INJ), has changed its format to mandatory written English, and has attempted to become more globalized over the last 3 years. In the next 3 years, our journal aims to be a forum for discussion and communication between readers and researchers. What should we strive for?

First, as researchers, we should not engage in time-consuming competition for acceptance of submitted journal articles. In addition, we should increase the global competitiveness of domestic journals, such as our journal. Competition between domestic researchers in foreign journals is time-consuming, as it uses our material for overseas benefits. In order to improve the quality of our journal, we need to conduct high-level discussions between the majority of members who have average knowledge, and we need to increase international competitiveness through the effort of our editors and staff. In order to make use of excellent related areas, an integrated academic journal should play the role of linking such areas.

Following epoch-making medical questions and projects, new technology and successes produced by medical star researchers have always followed. The concept of hygiene, antibi- otics, anesthesia, vaccination, the discovery of the structure of DNA, and evidence-based medicine are examples. In the climb to academic excellence, overseas academic journals that have shared groundbreaking medical progress have faced the problem of what to do after reaching the summit. In general, most journals return to their average standard after reaching the top. However, some journals chose to differentiate themselves from their previous level, by choosing selected pieces of work that move the journal in the editors' desired direction. These efforts make their journals distinct, and enable the journals to perform the role of leading and guiding researchers.

What will the future be like? Our journal will fuse work that is unfamiliar to the majority of average researchers with peerreview evaluation, in order to create new knowledge. In the age of information, those who create knowledge rule society. Therefore, the gap between information poor and rich readers will increase. However, medical opinions and results should not be monopolized by a selected few.

The stages of growth of a journal are in the following order: accumulation of funds to establish an on-line submission system, unification of language into English, and invitation of high quality journal articles that can increase the citation index. After that, the journal should attain an increase in the Science Citation Index (SCI) ranking.

The INJ is the only one of its kind in Asia that specializes in this particular field. The 2013 impact factor shows that the journal improved itself by $85 \%$ is acknowledgeable. In addition, the research-funded thesis and dissertation numbers are high, and such trends show that the number of foreigners contribut- 
ing to the journal is on the rise. In this issue [1], to have an opportunity to look back on some of our work, we have replaced the review article with an original article from our collection of special issues. In our fields of study, many of our colleagues and readers are acknowledging that having a unique style of manuscripts published in our journal is increasingly important. It is now imperative that we make advancements, not solely by using the SCI citation index alone, but through other channels as well.

Our journal is at this point of progress. In order to gain global competition for submission, we editors should ponder over how to accurately evaluate submitted manuscripts in order to achieve this goal.

\section{CONFLICT OF INTEREST}

No potential conflict of interest relevant to this article was reported.

\section{REFERENCE}

1. Huh S. How far has the International Neurourology Journal progressed since its transformation into an English language journal? Int Neurourol J 2014;18:3-9. 